\title{
Hisbah (Supervision) Application in Determining of Standarize Stadard Akad Modes on Islamic Financial Instituion in Indoensia
}

\author{
${ }^{1}$ Prawitra Thalib \\ Faculty of Law, Airlangga University \\ Surabaya, Indonesia \\ prawitra@fh.unair.ac.id \\ ${ }^{2}$ Hilda Yunita Sabrie \\ Faculty of Law, Airlangga University \\ Surabaya, Indonesia \\ hilda_sabrie@yahoo.co.id
}

\author{
${ }^{3}$ Faizal Kurniawan \\ Faculty of Law, Airlangga University \\ Surabaya, Indonesia \\ faizal_law@yahoo.co.id \\ ${ }^{4}$ Erni Agustin \\ Faculty of Law, Airlangga University \\ Surabaya, Indonesia \\ erni@fh.unair.ac.id
}

\begin{abstract}
As an intermediary institution based on sharia principle, sharia banks are required to performing two compliance namely compliance syariah principle and law compliance, as for th application of two compliance is it not only in good corporate governance and the kind of product sharia bank, but also on financing deed made by a notary. Therefore financing deed in sharia banks must reflect sharia compliance principle besides the law compliance, special concern about sharia compliance, has become scope authority from the Sharia Supervisory Board, in this term Sharia Supervisory Board not only ensure the application of sharia compliance but also every deeds which was built by a notary sharia bank must to be in accordance with the sharia principle. Failure on the fulfillment of the shariah principle on a sharia bank financing deed can led to such deed null and void, so that in this case application of sharia principle should be given to the aspect of protection sharia banks and consumer protection which took the form of the superintendence of the Sharia Supervisory Board to every sharia bank financing deed.
\end{abstract}

Keywords-Sharia Bank; Sharia Supervisory Board; Sharia Compliance; Finance Deed.

\section{INTRODUCTION}

Islamic banks are starting to become the newbig-thing of Indonesia, a country where most of the citizens are Muslims. Syariah Bank is one application of Islamic economic system, and part of the Islamic teachings, that regulate the economic field of its people who are inseparable from other aspects of Islamic teachings that are comprehensive and universal. Comprehensive means that the teachings of Islam summarize all aspects of life, 1 both ritual and social value that are universal. While the universal meaning that Islamic sharia can be applied in any time and place regardless of race, ethnic, class and religion according to Islamic principles "rahmatan lil alamin". Whereas the four main principles in sharia that always underlies the banking network with the system of sharia are:

1. Non-usury banking;

2. Commerce that is halal and not haram;

3. The ridha of each parties in contract; and

4. Trustworthy, honest, and responsible management of funds.

Referring to the growth of sharia banks that are accompanied by the needs of the community for sharia banking, 3 then the Otoritas Jasa Keuangan (hereinafter referred to as OJK), need to make further efforts to encourage the development of sharia banking to grow healthy and consistent in implementing sharia principles and widespread to reach all levels of society in need. To achieve this, OJK seeks to complement and refine existing provisions in accordance with the characteristics of the Regulation of Otoritas Jasa Keuangan (hereinafter referred to as ROJK) and other supporting regulations as the implementation of the Banking Law, so that it will directly or indirectly 
increases public awareness on sharia banking, encouraging the growth of sharia banking to all potential areas and improving the quality of Islamic resources, as well as to review the implementation of Sharia Financial Institution products (hereinafter referred to as SFI).

To align the existence of sharia banks, OJK and Bank Indonesia cooperate with the Majelis Ulama Indonesia (hereinafter referred as MUI). This cooperation is done, considering that MUI is an institution that has been the main source of implementation of sharia principles in Indonesia, so it is expected to result in effective and consistent sharia banking management in Shariah principles. This form of cooperation is with the establishment of the National Sharia Board (hereinafter reffered as NSB) and Sharia Supervisory Board (hereinafter reffered as SSB). Sharia banks and conventional banks, although moving in the same field, have different elements, proponently the requirement of NSB in the organ of the Islamic banking office based in sharia bank head office and possesses the position equal to the Board of Commissioners. As well as at each bank, the determination of the members of SSB is done through the General Meeting of Shareholders, this is to ensure the effectiveness of any opinion given by SSB.5

Roles and Functions of the National Sharia Board and Sharia Supervisory Board

The NSB is an institution under the MUI which was established in early 1999. This institution is assigned with assessing, reviewing and formulating the values and principles of Islamic law to serve as guidelines for institutionalized transaction activities sharia finance as well as overseeing its implementation and implementation. To perform its duties, the NSB has the authority to make a fatwa or rules relating to all Islamic banking transactions. 6

In addition to producing effective and consistent shariah banking under Shariah principles, a SSB is established, which is a body within a syariah bank and is responsible for overseeing business activities and operational activities of sharia banks in accordance with the principles and aspects of sharia banking with a fatwa issued by the NSB. In implementing such duty, SSB is also assigned to communicate suggestions regarding the development of Islamic banking products and services to NSB. SSB is responsible for products and services offered to the community in accordance with sharia principles, as well as in the field of investment or projects handled by sharia banks, and of course sharia banks must be conditioned in accordance with the principles of sharia. 7

Sharia banks in conducting their business activities must bound to Law Compliance and Sharia Compliance in order to maintain public trust towards the fulfillment of Sharia Compliance principles. When running its business activities, especially in terms of financing, Islamic banks always use the instrument of contract or contract made by the notary to accommodate the wishes of Islamic banks and customers. Therefore, in making the contract between sharia banks and customers, a notary must also pay attention to Law Compliance and Sharia Compliance simultaneously. Therefore, the contract made by the notary does not violate the principles of sharia as stipulated in Article 2 of Law Number 21 Year 2008 concerning Sharia Banking (hereinafter reffered as Law No. 21/2008). Due to the obligation of notary to apply Law compliance and Sharia Compliance, in such case, the notary should be supervised by SSB as the guarantor that the bank through notary services in running its business activities do not violate the principles of sharia and can maintain public trust.

SSB is an independent body endorsed by the NSB on banks and sharia financial institutions. SSB members should consist of experts in the field of sharia muamalah who also have knowledge in the field of banking economy. In the implementation of daily tasks, SSB shall follow the fatwa of NSB which is the highest authority in issuing fatwas regarding the products and services of banks with the provisions and principles of sharia. SSB's main task is to oversee the bank's business activities in order not to deviate from the provisions and principles of sharia that have been filed by the NSB. 8

Based on Article 35 paragraph (1) of the Regulation of Bank Indonesia Number 11/3 / PBI / 2009 , in general, the duty and function of SSB is to provide advice and advice to the Board of Directors and to supervise bank activities in accordance with sharia principles. Furthermore, in paragraph (2) it is stipulated that the implementation of SSB duties and responsibilities as referred to in paragraph (1) shall include: 
1. Assess and ensure compliance with Sharia Principles on operational guidelines and products issued by banks;

2. Supervise the process of new product development of the bank;

3. Requesting a fatwa from the NSB for new bank products that have no fatwa yet;

4. Perform periodic review of Sharia Principle fulfillment on fund raising mechanism and fund intermediary and bank service; and

5. Requesting data and information related to sharia aspects of the working unit of the bank in the framework of execution of its duties.

The functions and duties of the SSB as stipulated in the Decision of the NSB of the MUI Number 2 of 2000 on the Guidelines of the Household of the NSB of the MUI, that the SSB in each financial institution has the following main duties:

1. Provide advice and advice to directors, head of sharia business unit and head of sharia financial institution branch on matters related to sharia aspect;

2. Conduct supervision, both actively and passively, especially in the implementation of the fatwa of the NSB, and provide direction / supervision on products / services and business activities in accordance with the principles of sharia;

3. As a mediator between sharia financial institutions with the NSB, in communicating proposals and suggestions for the development of products and services from Islamic financial institutions that require review of the fatwa of the NSB.

In the theory of corporate law, the doctrine of fiduciary duty is known, the theory which emphasizes that a person who in the case of performing his duty acts for and on behalf of the other is based on a trust relationship. The trust relationship includes trust as a trustee and trust as an agent. Based on this it can be concluded that the task of SSB in a sharia bank outline includes two main tasks, namely: 9
1. Liabilities in the management of a sharia bank (a trustee) by supervising the implementation of sharia principles in sharia banks; and

2. Obligation to perform the functions of representatives of sharia banks (as an agent) in the communication of fatwas with the National Sharia Council of the Majelis Ulama Indonesia (NSB-MUI) and reporting to Bank Indonesia related to the supervision on the implementation of shariah compliance of a sharia bank.

Supervision in the Islamic view itself is done to straighten the unrighteous, correct the wrong and justify the right. Supervision (control) in the teachings of Islam (sharia law) at least divided into two things, namely control derived from monotheism and faith in Allah SWT and supervision consisting of supervisory mechanisms of leaders relating to the completion of tasks and planning tasks and others. To enforce supervision so that the implementation of banking in accordance with sharia principles and prevailing laws and regulations, the NSB-MUI establish SSB in every syariah financial institution. The objective of SSB establishment is to carry out supervisory function on sharia aspect in banking, although technically, syariah banking supervision remains OJK's authority.

One of the efforts to strengthen the industry of finance companies by improving the quality of good corporate governance, OJK issues Regulation of OJK Number 30 / POJK.05 / 2014 on Good Corporate Governance for Financing Companies. In the regulation there is a special rule of SSB in Chapter VII of Article 32 - Article 42. Whereas the regulation pertaining to ROJK financing is arranged within Article 38, namely:

1. SSB shall perform the task of supervising and giving advice and advice to the Board of Directors for the activities of Sharia Financing Companies in accordance with sharia principles;

2. Implementation of supervisory and advice duties performed by SSB as referred to in paragraph (1) shall be conducted on:

a. Sharia financing activities;

b. Sharia financing contracts marketed by Sharia and Islamic Financing Companies; and 
c. Shariah Financing Marketing Practices conducted by Sharia Companies and UUS.

3. In performing the duties of supervision and giving advice as referred to in paragraph (2), SSB may be assisted by committee members and / or employees whose organizational structure is under the Board of Commissioners and / or Board of Directors.

Financing products offered by sharia banks in Indonesia are numerous to meet both business and personal needs. The contracts used by these financing products mostly use murabahah, mudaraba and musyarakah schemes. Due to the many types of financing and existing contracts, the SSB should be required to continue to oversee the financing activities in order to avoid any deviations from the Sharia principles either in the form of a contract made by a notary or in the execution of financing activities after or before the contract is made. SSB's active role is necessary to verify the deeds reinforced by the notary so as not to deviate from the principles of sharia.

\section{LEGAL CONSEQUENCES FOR DEED / AKAD NOT IN ACCORDANCE WITH SHARIA PRINCIPLES (SHARIA COMPLIANCE)}

Legal consequence is the consequences of legal events. A legal event is caused by a legal act,10 while a legal act may also be interpreted as a result arising from the existence of a legal act and / or legal relationship.11 Meanwhile, according to Syarifin, legal consequence are all the consequences that occur from all legal acts committed by legal subjects to the object of law or other consequences caused by certain events by the law concerned has been determined or considered as a legal effect.12 The consequences of the law itself can be shown as:

1. The birth, change, or disappearance of a state of law. E.g: when a person reach age of 21 (twentyone) years old, he who is initially incompetent, turns into a competent subject before the law;

2. The birth, change, or disappearance of a legal relationship, between two or more legal subjects, in which the rights and duties of the other party deal with the rights and obligations of the other. E.g: purchase agreement;

3. The birth of sanctions if the act is unlawful;

4. Legal consequences arising from the existence of emergency events by the law concerned have been recognized or deemed as a legal consequence, although under reasonable circumstances they may be prohibited by law.

In the making of the deed of sharia, the notary must fulfill the requirements of the validity of the agreement in BW, the provisions of Law Number 2 Year 2014 concerning Amendment to Law Number 30 Year 2004 regarding Notary Position (UUJN), and the provisions in Law no. 21/2008. A deed of an agreement, if it does not meet the legal requirements of the agreement then the deed may be canceled (vernietigbaar) or null and void (nietig). An agreement that does not meet the objective requirements, ie certain objects and prohibited powers, then the agreement is null and void. Nullifying by law has the meaning that the legal act is considered never existed and is not a legitimate legal product.

If an agreement does not meet the subjective requirements, i.e agreement of those who commit themselves and the ability to make an engagement, then the agreement may be canceled. Can be canceled here, meaning that the cancellation request can be filed in court by proving that the subjective requirements are not met. If it does not submitted for cancellation before the court, then the agreement applies to the parties. If the dispute on the request for the judgment of the notarial notarial deed it is then must be examined by the judge, it will be proved in advance of the trial regarding the nature of the evidentiary power of deed from the formal aspect to the material aspect, which then results in the legal effect of the deed having an outright proof power or not. The judge's examination relates to the intervention of the judge in the case of examining the agreement or notarial deed. The judge will decide whether the violation of the agreement or notarial deed is null and void or may be canceled. The verdict has different consequences, because if it violates the subjective terms, it will result in the agreement or the deed may be canceled, whereas if it violates the objective requirement, then the deed is null and void.13 
Regarding the deed or sharia bank account, the format of the document is not regulated in Law no. $21 / 2008$, so that the format of the agreement in the sharia bank is generally uniform and almost the same as the general agreement format, because it is subject to the provisions and according to the customs prevailing among Indonesian legal practitioners. Thus, the validity of the syariah bank acts besides having to comply with Article 38 UUJN, also must fulfill the requirements of sharia law, that should not contain elements of gharar, masyir, riba, zalim, risywah, haram and maksiat goods.14

All notaries are authorized to make deeds as long as desired by the parties or according to the rule of law shall be made in the form of an authentic deed, not with the exception of the syariah bank deed. The making of a deed of a sharia bank must be based on the legal rules relating to the procedure of notarial deed and sharia principles.15 In making the Islamic bank deed, the notary is required to understand very well about the contents of syariah bank contract with the customer. In addition to using the existing legal principle (law compliance), a notary must also observe sharia principles (sharia compliance) in making a deed. A contract is said not to violate the principles of sharia if it does not violate the provisions of Article 2 of Law no. 21/2008, namely sharia banking in conducting its business activities based on sharia principles, economic democracy, and prudential principles. Business activities based on sharia principles, among others, are nonelementary business activities:

1. Riba, namely the addition of unauthorized income (batil), among others, in the exchange of similar goods transactions that are not the same as the quality, quantity, and time of delivery (fadhl), or in a lending-borrowing transaction which requires the recipient of the facility to refund the received funds exceeding the principal of the loan as the proceeds time (nasi'ah);

2. Maisir, i.e transactions that are based on an uncertain and lucrative circumstance;

3. Gharar, namely transactions whose objects are unclear, not owned, not yet known to exist, or can not be submitted at the time of the transaction unless otherwise stipulated in sharia;

4. Haram, i.e transactions whose objects are prohibited in shariah; or
5. Zalim, i.e transactions that cause injustice to others.

Article 1 Sub-Article 13 of Law. 21/2008 has stipulated that "a contract is a written agreement between a sharia bank or UUS and any other party which contains rights and obligations for each party in accordance with sharia principles", if there is a contract that does not meet or is contrary to sharia principles then the contract may be interpreted null and void, this is based on Article 28 point 3 of the Compilation of Islamic Economic Law (hereinafter reffered as CIEL) stating that "a canceled contract is a less harmonious contract and / or conditions", therefore, if the deed or covenant the notary is not in accordance with the existing legal principles and violates the principles of sharia, then the deed is null and void.

Whenever the deed or contract is legal and fulfills the terms and conditions, but in the use of the purpose of the financing, the customer misuses the funds by performing prohibited actions and is not in accordance with the principles of sharia, the customer may be said to have broken the promise or wanprestasi. Breach of promise or default is a condition in which the customer does not do what he promised or the customer does not fulfill his performance. Mentioned in Article 36 of $\mathrm{CIEL}$, the party may break the promise if it is:

1. Not doing what it promises to do;

2. Conducting what is promised but not as promised;

3. Do what promised, but too late; or

4. Doing something that the agreement should not be done.

Parties in a contract that breaks a promise may be subject to sanctions in the form of paying compensation, cancellation of the contract, the transfer of risk, a fine, and or paying a court fee. The indemnity payment sanction may be imposed if:

1. A party who breaks a promise after declared to have broken the promise, keep doing so; 
2. Anything that must be given or made, can only be given or made within the timeframe that it has passed;

3. A party who breaks a promise can not prove that the disobedient acts committed are under duress.

Related to the above, the legal protection for Islamic banks can be divided into 2 (two) namely the protection of internal law and protection of external law, the first concerning the protection of internal law that serves for sharia banks to implement sharia principles (sharia compliance). This is done by means of SSB and syariah bank compliance organs must verify the deed or contract made by a notary before being signed by the bank and the customer. Meanwhile, the external protection has not been set specific norms. However, OJK may provides legal protection by providing recommendations to the supervisory board in order to provide sanctions if there is a notary that makes the deed is not in accordance with the principles of sharia (sharia compliance). So far, the existing legal protection is only at the point of emphasis for customers, but not for sharia banks (e.g regulated in laws and ROJK governing consumer protection). It is strongly suggested that the protection of the law must be balanced between the bank and the customer, so that both parties feel safe when doing financing activities.

\section{SANCTIONS FOR NOTARY THAT IS NOT COMPLYING WITH SHARIA PRINCIPLES}

Sanctions are an essential part of the law and every rule of law prevailing in Indonesia is always provided with sanctions. The imposition of sanctions in Indonesia does not only exist in the form of law, but may be in the form of other regulations under the law. Inclusion of sanctions in the various rules of law is an obligation that must be included in each rule of law, whereas it may took criminal, civil, and administrative sanctions. It is affirmed that a violator can be subject to cumulative sanctions. The relevant legal rules can not be enforced or will not be obeyed if at the end does not include sanctions. There is no point in enforcing the rule of law when it can not be imposed through sanctions and enforce it procedurally.16
Sanctions against notary are provided in Article 84 and Article 85 of the UUJN, those are:17

\section{Civil Sanction}

Sanctions in the form of reimbursement of expenses, compensation and interest shall be the result that will be received by the notary on the complaint's demands if the deed concerned only has the evidentiary power as a deed under the hand or deed becomes null and void.

Notarial deeds that have perfect proof power, for violating certain provisions, will undermine the value of proofing to have a proof power as a deed under the hand. The position of a notary deed which then has the evidentiary power as a deed under the hand constitutes an assessment of an evidence.

While a deed is null and void, then the deed is considered never existed or never made. Something that is never made can not be the basis of a claim in the form of reimbursement of costs, compensation, and interest. Therefore, a notarial deed that is null and void shall not result in a reimbursement of fees, compensation and interest to the parties in the deed. Reimbursement of costs, damages and interest may be required by a notary must be based on a legal relationship between a notary and the parties to the notary. If any party harmed directly from a notarial deed, then it may submit a lawsuit.

Article 84 of the UUJN is its stipulation provides 2 (two) types of civil sanctions, if the notary commits a violation of certain Articles, namely:

a. Notarial deeds have evidentiary power as deeds before the law; dan

b. The notarial deed becomes null and void.

Thus, it can be concluded that a notarial deed which has the evidentiary power as a deed before the law, if expressly stated in the relevant Article, if not expressly stated then included as a deed becomes null and void.

\section{Administrative Sanction}

In Article 85 UUJN, it mentioned 5 (five) types of sanctions, i.e: 

a. Verbal reprimands;
b. Written reprimands;
c. Dismissal with respect;
d. Dismissal without honor.

Ten Berge asserts that law enforcement instruments include supervision and enforcement of sanctions. Supervision is a preventive effort to enforce compliance, and repressive efforts to enforce compliance.18 In the application of administrative sanctions against notaries who become the watchdog instruments, the Supervisory Council takes the preventive measures, to impose compliance, to apply repressive sanctions, and to impose compliance so that sanctions can be implemented. Preventive measures shall be undertaken with periodic inspections once a year or at any time deemed necessary to check the notarization of the notary in the performance of his / her office of office viewed from the protol examination by the District Supervisory Board (hereinafter reffered as DSB). Then DSB may inform the Regional Supervisory Board (hereinafter reffered as RSB), on reports received by the DSB, if there is any criminal element to be found. Then can hold a hearing to check the alleged violation of a notary code of ethics or a violation of the execution of a notary.

While MPW can carry out repressive effort by imposing sanction in the form of written or oral warning and final sanction (Article 73 paragraph (1) letter e and paragraph (2) UUJN), and propose sanction against notary by Central Supervisory Board:

a. Temporary discharge for 3 (three) months up to 6 (six) months; or

b. Dismissal without honor.

Sanctions in Articles 85 and 86 of the UUJN apply in stages ranging from verbal reprimands to dismissal without honor is internally sanctioned. Internal sanctions namely sanctions against a notary in carrying out his duties do not perform a series of orderly conduct of duties of notary work that must be done for the benefit of the notary itself.

\section{Criminal Sanction}

Criminalization of a notary can be made with a limit whenever:

a. The legal act of a notary to the formal aspects which is deliberately, consciously and planned, that a deed made by or in the presence of a notary which agrees to serve as a basis for committing a crime;

b. The legal action of a notary in making a deed by or in the presence of a notary which if tested is contrary to UUJN;

c. The act of notary is not appropriate according to the authorized

institution to assess the act of a notary, in this case the Notary Public Notary.

The imposition of criminal sanctions on a notary can be made to the extent that the above limits are violated, meaning that in addition to fulfilling the formulation of the violations contained in the UUJN and the Code of Ethics of Notary Public, must also fulfill the elements referred to in Article 322 paragraph (1) and (2) of the Criminal Code about dismantling secrets, which the notary public should be obliged to keep. Criminal sanctions are ultimum remidium, the last weapon, as sanctions or attempts used in other branches of law are incapable or considered to be impervious to overcome. Therefore, its use should also be limited. If it still can be overcomed then it should be avoided to use the criminal sanction.19

\section{CONCLUSION}

Raison d'etre of the need for supervision by SSB on notarial deeds in syariah banks is to ensure the implementation of the principles of sharia in the practice of sharia banking in Indonesia. Implementation of sharia principles in kaffah is very important in maintaining the reputation of Islamic banks and increasing public confidence in Islamic banking institutions in Indonesia, to ensure that a sole reliance on syariah bank is not enough. However, in practice such efforts should also be in accordance with the application of sharia principles in kaffah by a notary who makes the deeds of Islamic banks. The party that has the authority to guarantee the application of Sharia Compliance in the practice of syariah bank is SSB, this is as regulated in Article 32 number 3 of Law no. 21/2008, in performing its 
duties, SSB does not supervise the activities of sharia banks but also widely supervises the substance of notary deeds of Islamic banks, in order to guarantee the application of Sharia Compliance thoroughly.

Therefore, the legal consequences of deeds that are not in accordance with the principles of sharia are null and void. Hence, it can be understood that the fulfillment of Sharia principles is very important in order to maintain the fulfillment of harmonious and the terms of a contract, because without the fulfillment of sharia principles a contract, then the contract can not be said to have harmonious and perfect terms, if the rukun and the conditions are not perfect then automatically the contract is null and void. Therefore, a synergy between the notary actors as the author of the certificate and the SSB is required to verify the deed.

\section{REFERENCES}

\section{Books}

[1] Jafri Khalil, "Prinsip Syariah dalam Perbankan", Jurnal Hukum Bisnis Vol.20, 2002.

[2] Dimas Aryo Wicaksono, Pengawasan Kegiatan Usaha Pada Bank Syariah, Skripsi, Fakultas Hukum Universitas Airlangga, 2003.

[3] Heri Sudarsono, Bank dan Lembaga Keuangan Syariah Deskripsi dan Ilustrasi, Ekonisia, Jogjakarta, 2003.

[4] Tim Pengembangan Perbankan Syariah Institut Bankir Indonesia, Djambatan, Jakarta, 2007.

[5] Adrian Sutedi, Perbankan Syariah, Ghalia Indonesia, Bogor, 2009.

[6] Freddi Harris, Teddy Anggoro, Hukum Perseroan Terbatas: Kewajiban Pemberitahuan oleh Direksi, Ghalia Indonesia, Jakarta, 2010.

[7] Ishaq, Dasar-Dasar Ilmu Hukum, Sinar Grafika, Jakarta, 2009.

[8] Pipin Syarifin, Pengantar Ilmu Hukum, Pustaka Setia, Bandung, 2009.

[9] Novita Kartikasari, Pertanggungjawaban Notaris Dalam Pembuatan Akta dan Akibat Hukumnya, Tesis, Magister Kenotariatan Fakultas Hukum, Universitas Airlangga, Surabaya, 2010.

[10] Lilies Pratiwipuspa, Keabsahan Akta Akad Bank Syariah Yang Dibuat Oleh Notaris Yang Tidak Bersertifikat Lembaga Keuangan
Syariah, Tesis, Magister Kenotariatan Fakultas Hukum, Universitas Airlangga, Surabaya, 2010.

[11] Philipus M.Hadjon, Pengantar Hukum Administrasi Indonesia, Gadjah Mada University Press, Yogyakarta, 2002.

[12 Syailendra Alam Wienantya, Sanksi Terhadap Notaris Atas Pelanggaran Kewajiban Terkait Dengan Pembuatan Akta, Tesis, Magister Kenotariatan Fakultas Hukum, Universitas Airlangga, Surabaya, 2009.

[13] Sudarto, Hukum Pidana I, Badan Penyedia Bahan-Bahan Kuliah Fakultas Hukum Universitas Dipenogoro, Semarang, 1987/1988, h.13.

\section{Regulations}

[14] Undang-Undang Nomor 21 Tahun 2008 tentang Perbankan Syariah, Lembaran Negara Republik Indonesia Tahun 2008 Nomor 94.

[15] Undang-Undang Nomor 2 Tahun 2014 Tentang Perubahan Atas Undang-Undang Nomor 30 Tahun 2004 Tentang Jabatan Notaris, Lembaran Negara Republik Indonesia Tahun 2014 Nomor 3.

[16] Peraturan Mahkamah Agung Republik Indonesia Nomor 2 Tahun 2008 Tentang Kompilasi Hukum Ekonomi Syariah.

[17] Peraturan Bank Indonesia Nomor 11/3/PBI/2009 Tentang Bank Umum Syariah. Peraturan Bank Indonesia Nomor 13/23/PBI/2011 Tentang Penerapan

[18] Manajemen Resiko Bagi Bank Umum Syariah dan Unit Usaha Syariah. Peraturan Otoritas Jasa Keuangan Nomor 1/POJK.07/2013 Tentang

[19] Perlindungan Konsumen Sektor Jasa Keuangan.

[20] Peraturan Otoritas Jasa Keuangan Nomor 30/POJK.05/2014 Tentang Tata Kelola

[21] Perusahaan Yang Baik Bagi Perusahaan Pembiayaan.

[22] Peraturan Otoritas Jasa Keuangan Nomor 31/POJK.05/2014 Tentang Penyelenggaraan Usaha Pembiayaan Syariah. 